\title{
Síelés, avagy hogy készítsük fel izmainkat a síszezonra? Skiing, or how can we prepare our muscles for the ski season?
}

\begin{abstract}
összizoghalás:
Síszezon előtt sokaktól halljuk, hogy készülnek a szezonra. Ez alatt többnyire a síeléshez szükséges eszközök (ruházat és sífelszerelés) megvásárlását, javíttatását értik. Ahogy a felszerelések is „pihentek" az előző szezon óta, úgy a síeléshez szükséges izomzatunk is sok esetben inaktívan töltötte ezt az időszakot. A sérülések megelőzése miatt a síelés során használt úgynevezett „sífunkciós” izomzatunkat is érdemes „felébreszteni", aktiválni az idény előtt. Írásunkban a síelés során leginkább igénybe vett izmok felkészítésére közlünk szárazföldi gyakorlatokat. A feladatok összeállítása az alapvető mozgásminták használatával történt. A gyakorlatok kiválasztása során azokra az izmokra fókuszáltunk, melyek elsődleges szerepet játszanak a síelés közbeni folyamatosan változó körülményekhez történő adaptációban, a stabilitás, illetve a mobilitás közti egyensúly megteremtésében.
\end{abstract}

Kulcsszavak: síelés, stabilitás, felkészülés, szárazföldi edzés

\section{- abSTRAGT: \\ Before the ski season we can hear from many peo-} ple that they are really preparing for it. By this they mean the purchase and repair of the neccesary equipment (ski wear and ski kit). Not only the equipment has been taking a rest since the last season, but also our ski funtional muscles has been inactive since then. Due to avoiding injures, it is worth waking up and activating our muscles needed for skiing befor the season.

Dryland exercises are given to prepare the mostly used muscles for skiing. The exercises have been compiled by using basic movement patterns. While selecting the exercises our focus was on such particular muscles which play the most important role in adapting to the changing circumstances during skiing as well as creating balance between stability and moblity.

Keywords: skiing, stability, dryland exercises

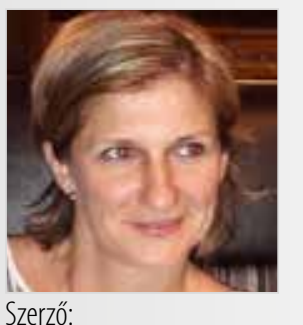

Szerzo"

BIRÓNÉ DR. ILICS KATALIN egyetemi adjunktus ELTESporttudományi Intézet birone.lics.katalin@ppk.elte.hu Főbb kutatási területei: rekreáció, kiválasztás, tehetséggondozás, versenysport

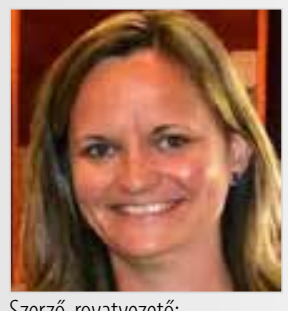

Szerző, rovatvezetō: DR. NAGYVÁRADI KATALIN egyetemi adjunktus ELTE Sporttudományi Intézet nagyvaradi.katalin@ppk.elte.hu Főbb kutatási területei: rekreáció, egészségfejlesztés, gyógytestnevelés

\section{BEVEZTÉS}

Magyarországon, a carving lécek megjelenése óta megsokszorozódott a síelők létszáma. $\mathrm{Az}$ International Report on Snow \& Mountain Tourism-ban megjelent 2017-es tanulmány szerint Magyarországon körülbelül félmillió ember síel vagy snowboardozik. Ez a magyar lakosság 5,6\%-a (Laurent V., 2017).

A Központi Statisztikai Hivatal adatai szerint Magyarországon a 15 évesnél idősebb emberek 58,2\%-a túlsúlyos vagy elhízott ( $K S H, 2019)$. Továbbá a magyar lakosság 67 \%- a nem sportol még napi 10 percet sem, és a magyarok közel fele többnyire ül a munkája során (KSH, 2015). Azoknak, akik évközben inkatív, ülő életmódot folytatnak, kizárólag csak a téli időszakban mozognak, azaz mindössze pár napot töltenek síeléssel, nagyobb hangsúlyt kell fektetniük a síeléshez szükséges izomzatuk felkészítésére. A megfelelő - a síelés specifikumait előtérbe helyező - feladatok rendszeres végzése felkészíti az egyén aktív és passzív szervrendszerét a ( $b a l-$ esetmentes) síelésre.

\section{A SIEELÉSHEZ SZÜKSÉGES FŐBB IZMOK, KÉPESSÉEEK}

A síelés alapiskolai gyakorlatai során az ízületi stabilitás van fókuszban (Stanley, 2005), azaz az ízület helyes anatómiai pozícióban való tartása, ami végig domináns marad a síelés mozgástanulási folyamata során (Demeter, Osváth, 2016).
Az ízületi stabilitást azok az izmok biztosítják, melyek közel helyezkednek el a mozgatott ízülethez, így teszik lehetővé azt, hogy ezen ízület csak olyan mozgásokat végezzen és akkora mozgáspályán, ami számára optimális. Ennek azonban elengedhetetlen feltétele ezeknek az izmoknak a megfelelő erő- és rugalmassági állapota. A síeléshez szükséges helyes testtartás a törzs stabilitásának köszönhetó. A megfelelő stabilitást a core izmok fejlesztésével érhetjük el. Ezen izmok feladata az ágyéki gerincszakasz stabilizálása, tehát azért felelősek, hogy az ágyéki szakaszon minden oldalról tartsák a gerincünket. Így elölről a hasizmok, hátulról a gerincfeszítő izmok és oldalról-hátulról a farizmok segítik a lumbális (ágyéki) gerincszakasz helyes pozícióban tartását és mozgatását.

A törzsstabilizáló izmokon túl, síelés során, talán a leginkább igénybe vett izom a négyfejü combizom (m. quadriceps femoris), továbbá a megfelelő lábmunkát biztosító farizmok ( $m$. gluteus maximus, medius, minimus), a kétfejü combhajlító izom ( $m$. biceps femoris), a combközelítő és további távolító izmai ( $m$. adduktor - longus, - magnus, - brevis, m. gracilis, $m$. pectineus; $m$. tensor fasciae latae, $m$. sartorius, $m$. piriformis), illetve a vádli (calvus) (Bogárdi, 2020). A síbot használata miatt nem feledkezhetünk meg a kar izmairól sem ( $m$. biceps brachii, a m. triceps brachii).

Az izmok rugalmasságát, az ízületi mozgáshatár növelését nyújtó és mobilizáló gyakorlatokkal érhetjük el. Nyújtó gyakorlatokkal az izmok rugalmasságát fejlesztjük, az izmok vagy 


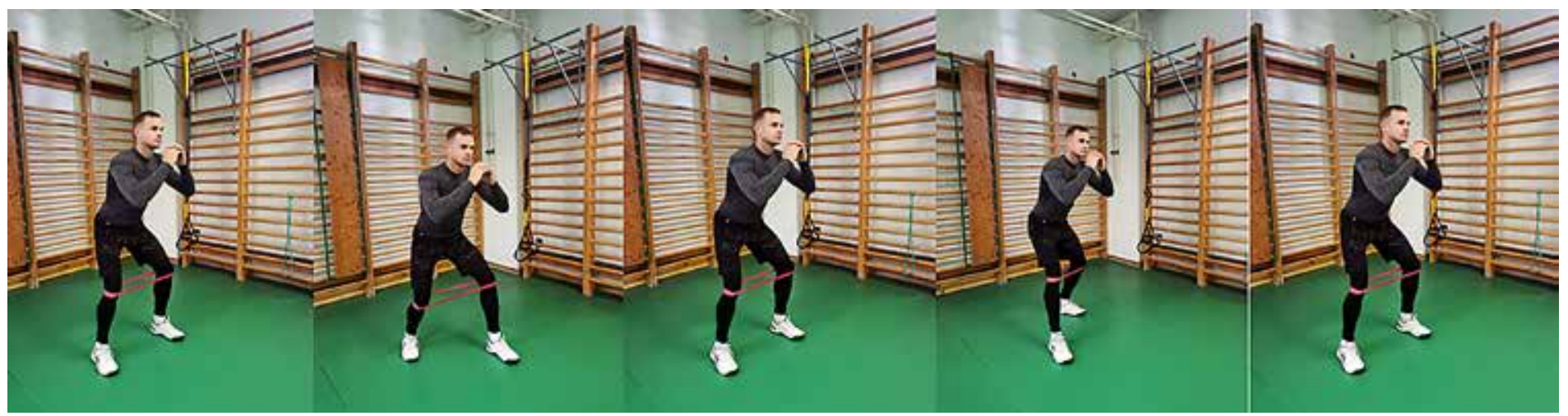

\section{1. ábra: Séta minibanddel a térd alatt}

izomcsoportok hossza megváltozik, ez pedig az adott ízületben elmozdulást hoz létre, mellyel növelhető annak mozgáshatára (Metzing, 2010).

Mobilizálás során a nem terhelt ízületek teljes mozgástartományában történik az átmozgatás.

A rendszeresen elvégzett mobilizációs gyakorlatok hozzájárulnak az erőfejlesztés során végzett gyakorlatok pontos, hatékony és biztonságos végrehajtásához.

A síelés technikai végrehajtása nem csak megfelelő izomerőt, hanem egyensúlyérzéket, illetve propriocepciót is igényel.

$\mathrm{Az}$ egyensúly az a vesztibuláris képesség, amely lehetővé teszi, hogy testünket a kívánt helyzetben vagy mozgásban tudjuk tartani változó testhelyzetek és mozgások közben (Polgár, Szatmári, 2011).

A propriocepció az ízületek helyzetének, állásának érzékelése, vagyis az egyensúly és a testérzékelés kombinációja.

A propriocepciónak fontos szerepe van az ízület védelmében és dinamikus stabilitásában, ami az agonista és antagonista izmok együttmúködésének eredménye (Balogh, 2013).

Fejlesztése változatos talajon, instabil felületen és/vagy csökkentett

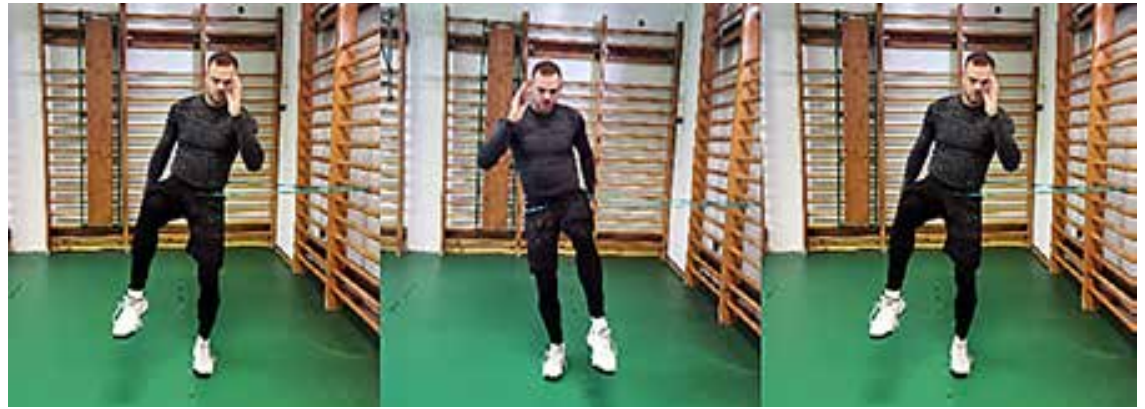

2. ábra: Szökkenés egy lábról egy lábra

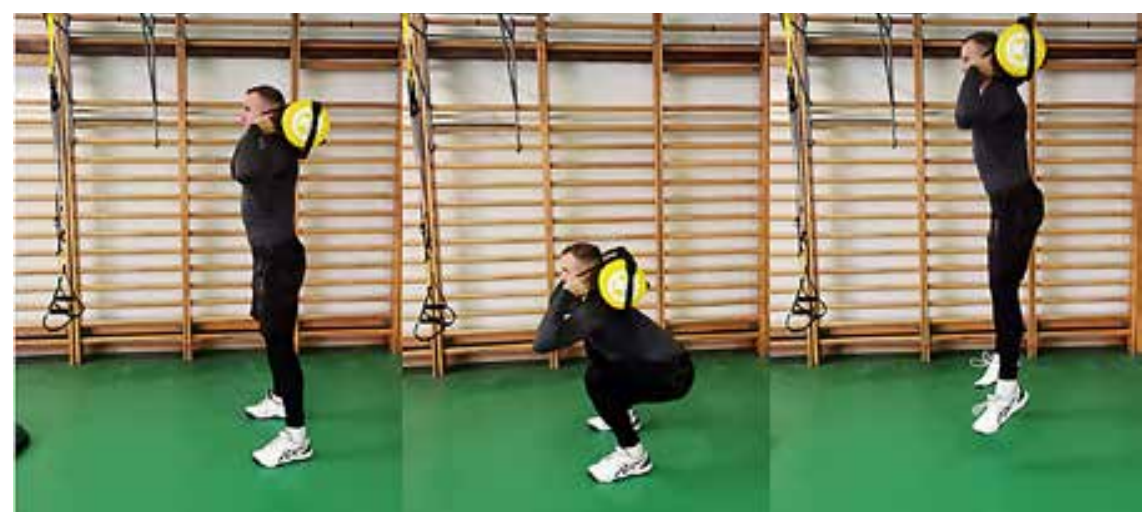

3. ábra: Guggolás - felugrás sandbaggel a vállon

alátámasztási felületen végzett gyakorlatokkal történhet. Megjegyezzük, hogy a síspecifikus gyakorlatok mellett a felkészülés során szem előtt kell tartanunk az állóképesség fejlesztését is, melyet különböző cardioprogramokkal érhetünk el.

\section{AZ IZMOK FELKÉSZZTÉSÉNEK MÓDSZEREI}

Mivel síelés során folyamatos egyensúlyvesztés következik be, illetve a változatos terep állandó alkalmazkodást követel meg az egyén-
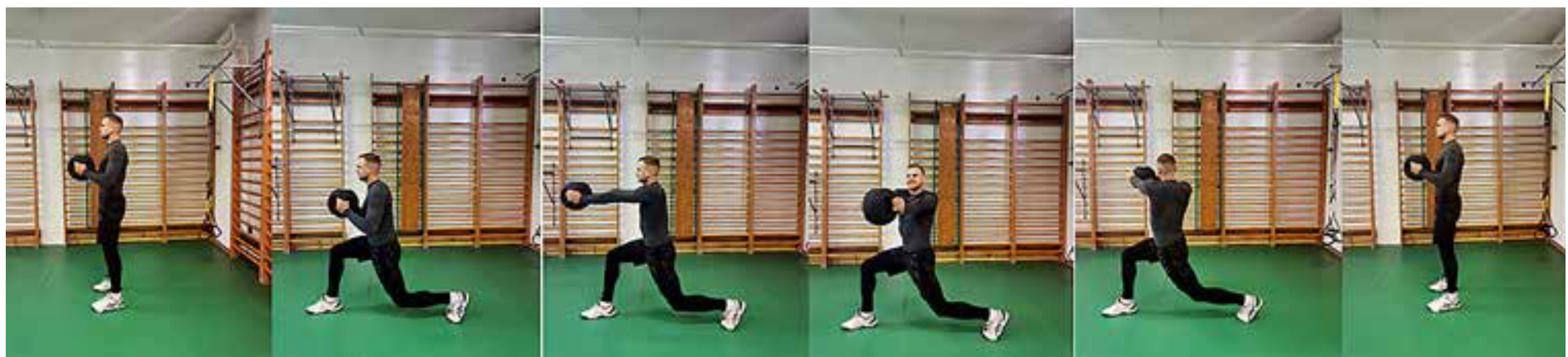

4. ábra: Kitörés előre, törzsfordítás mindkét irányba, medicinlabda-tartás mellső középtartásban 


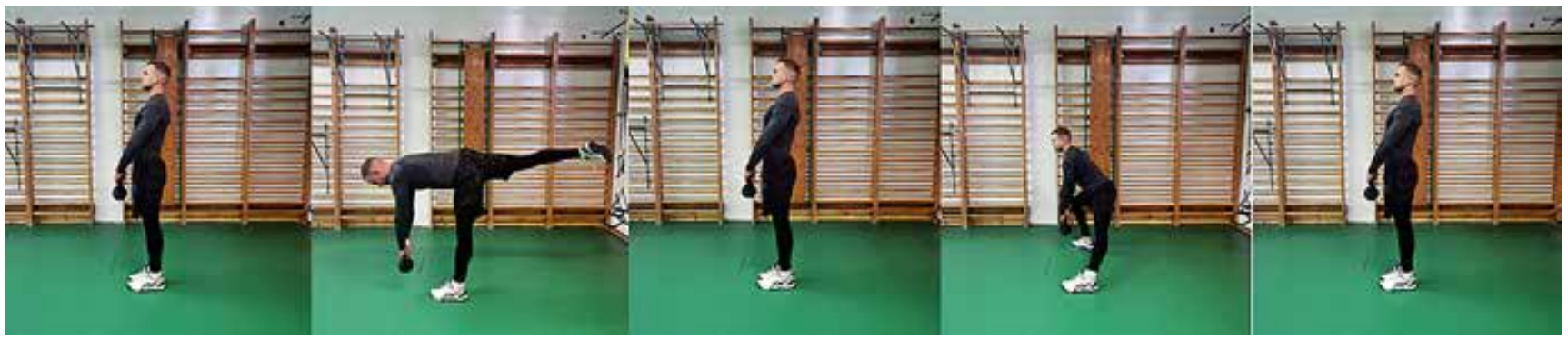

\section{5. ábra: Kiinduló helyzetből törzsdöntés elöre egylábon, kettlebellemelés mellső középtartásba, majd felhúzás után kitörés oldalra}

től, ezért a stabilizáló izmok fejlesztésének kitűnő eszközei lehetnek az instabil felületeken végzett gyakorlatok. „Instabil felületeknek nevezzük azokat a felszíneket, amelyeken a test alátámasztása bizonytalan, ingatag, használatuk során sorozatos egyensúlyvesztés következik be. Emiatt az egyensúly fenntartásában az összes izomnak folyamatosan részt kell vennie, korrigálnia kell, így azok automatikusan ellentartanak" (Nagyváradi és mtsai, 2020). Gyakorlatgyüjteményünkben a bosut használtuk instabil felületnek.

A dinamikusan fejlődő fitnesz trendnek köszönhetően, számos eszköz áll a rendelkezésünkre, a változatos és hatékony szárazföldi felkészüléshez. Gyakorlatainkhoz az alábbi eszközöket választottuk: TRX, power és mini bandek, kézisúlyzó, kettlebell.

A TRX a sajáttestsúlyos edzések „sztárja”. Funkcionális erőt épít, fejleszti a hajlékonyságot, az egyensúlyérzéket és a core izmok stabilitását. A power és mini bandek által nyújtott ellenállást, az erő, a sebesség és a gyorsulás, továbbá a hajlékonyság növelésére fejlesztették ki (https://www.gymstick.com/power-band.html). A kettlebell, egyszerúen fogalmazva egy fogantyúval ellátott vasgolyó. Az eltérő tömegben elérhető eszközzel fejleszthető az erő és a robbanékonyság.

\section{A SÉEIÉS SZÁRAZFÖLDI GYAKORLATAI}

A gyakorlatok elvégzése előtt feltétlenül szükséges az alapos bemelegítés - nyújtás, mobilizálás. Felhívjuk a figyelmet a feladatok pontos kivitelezésére, így célszerü először eszköz nélkül, saját testsúllyal dolgozni. Javasoljuk, hogy a gyakorlatokat mindenki az aktuális teljesítőképességének megfelelő ellenállással, intenzitással és ismétlésszámmal végezze. (Például kezdőknek javasoljuk a kisebb ellenállást, lassú, egyenletes intenzitású feladat-végrehajtást, maximum 5 ismétlésszámmal.)

\section{ÖSSZEZĹ́S}

Valamennyi mozgásforma elsajátítása hosszú távú, logikusan felépített folyamat eredménye. A síelés mozgás tanulása, illetve a síszezon előtt az ideg-izom kapcsolatok „felébresztése” során a szárazföldi gyakorlatok biztosítják a későbbi - havon végrehajtott - mozgásminták alapjait (a stabilitást, illetve a mobilitást), így kiemelten fontos szerepük van a helyes és balesetmentes mozgásvégrehajtásban. A sportágspecifikus (szárazföldi és havon végrehajtott) gyakorlatok előtt egyaránt lényeges az általános bemelegítés, a szervezet felkészítése a terhelésre.

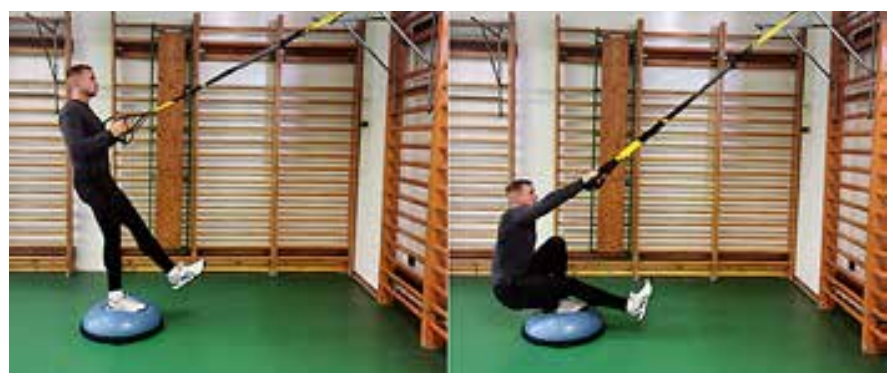

6. ábra: Egylábas mély guggolás bosun, TRX fogással

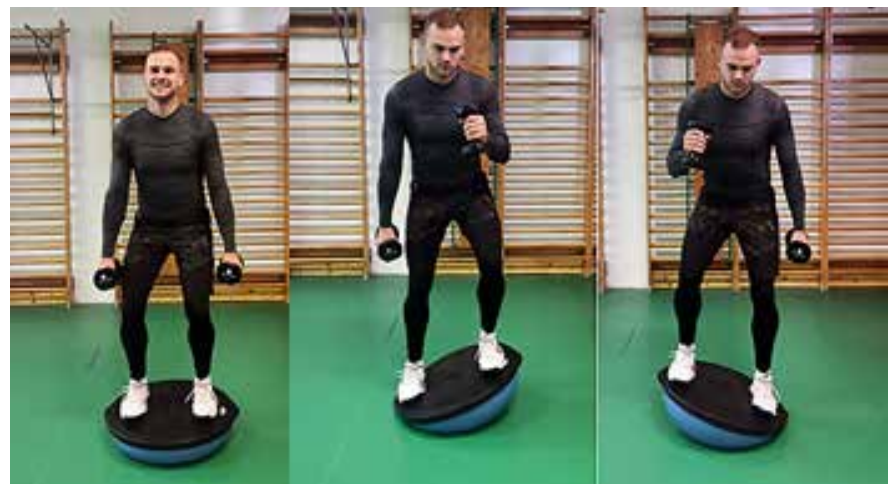

7. ábra: Felfordított bosu „,billegtetés”, súlyzóval könyökhajlítás - nyújtás

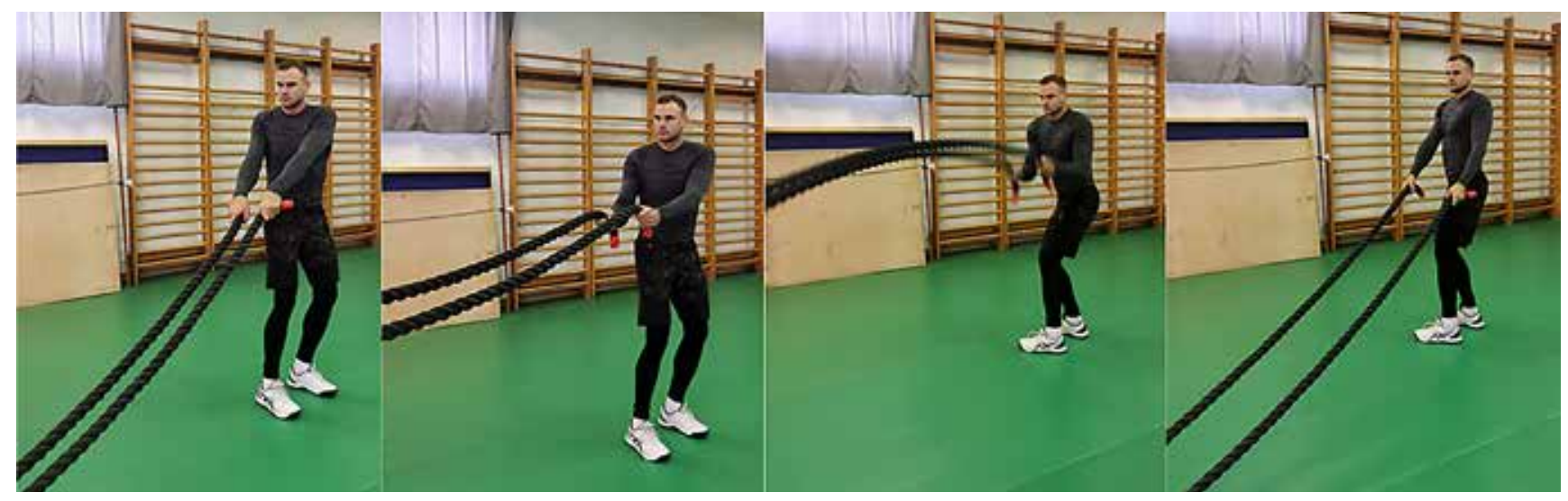

8. ábra: Kötélhajtás $2 \times$ jobb, majd $2 \times$ bal harántállásban 


\section{IRODALOMJEGYZÉKK}

Balogh J. (2013): Proprioceptív tréning. From: http://kosaredzo.hu/ proprioceptiv-trening/

Bogárdi I. (2020): A test izomzatának edzése. Bogger Kft.

Demeter A, Osváth M. (2016): Síoktatási segédlet tanároknak, síoktatóknak. Iskolai Síoktatók és Szabadidő-szervezők Egyesülete. Budapest

Dosek Á., Osváth M. (2004):

A sízés +3. Reálszisztéma. Dabasi Nyomda. Dabas

Központi Statisztikai Hivatal (2015): Európai Lakossági Egészségfelmérés, 2014. Statisztikai Tükör 2015. 29.

L. Vanat (2017): International Report on Snow \& Mountain Tourism
Metzing M. (2010): Gimnasztika. From: http://bszszsport.atw.hu/ pdf1/gimnasztika_jegyzet_2010.pdf

M. Boyle (2020): Funkcionális edzés újratöltve. Jaffa kiadó, Budapest.

Nagyváradi, K. - Biróné llics, K. - Polgár, T. - Ihász, F. (2020): Pulzusváltozások vizsgálata különböző instabil felületeken végzett gyakorlatok során. Recreation, 10/2., pp22-24. Budapest. DOI: 10.21486/ recreation.2020.10.2.3

National Academy of Sports Medicine (2013): NASM Essentials of Performance Training. Lippincott Williams \& Wilkins, Philadelhpia, US.

Polgár, T. - Szatmári, Z. (2011): A motoros képességek. Elektronikus tankönyv: Dialóg Campus KiadóNordex Kft. From: https://regi. tankonyvtar.hu/hu/tartalom/ tamop425/0025_Polgar_TiborSzatmari_Zoltan-Motoros_ kepessegek/adatok.html

Sahrmann S. (2002): Diagnosis and Treatment of Movemnet Impairment Syndromes. St. Louis: Mosby

Staley C.(2005): Muscle Logic: Escalating Density Training, Rodale Books.

Wolf C. (2017): Insights into Functional Training Perfect Paperback, On Target Publications https://www.gymstick.com/ power-band.html

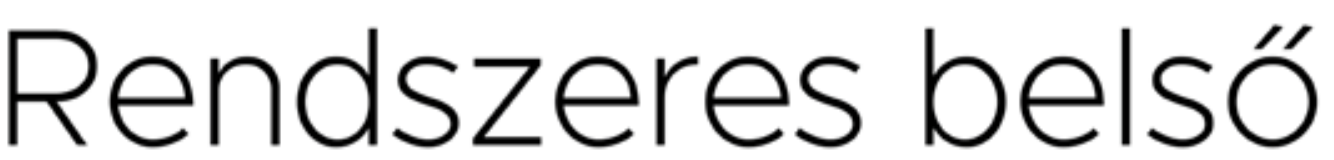
kapcsolat a természettel!
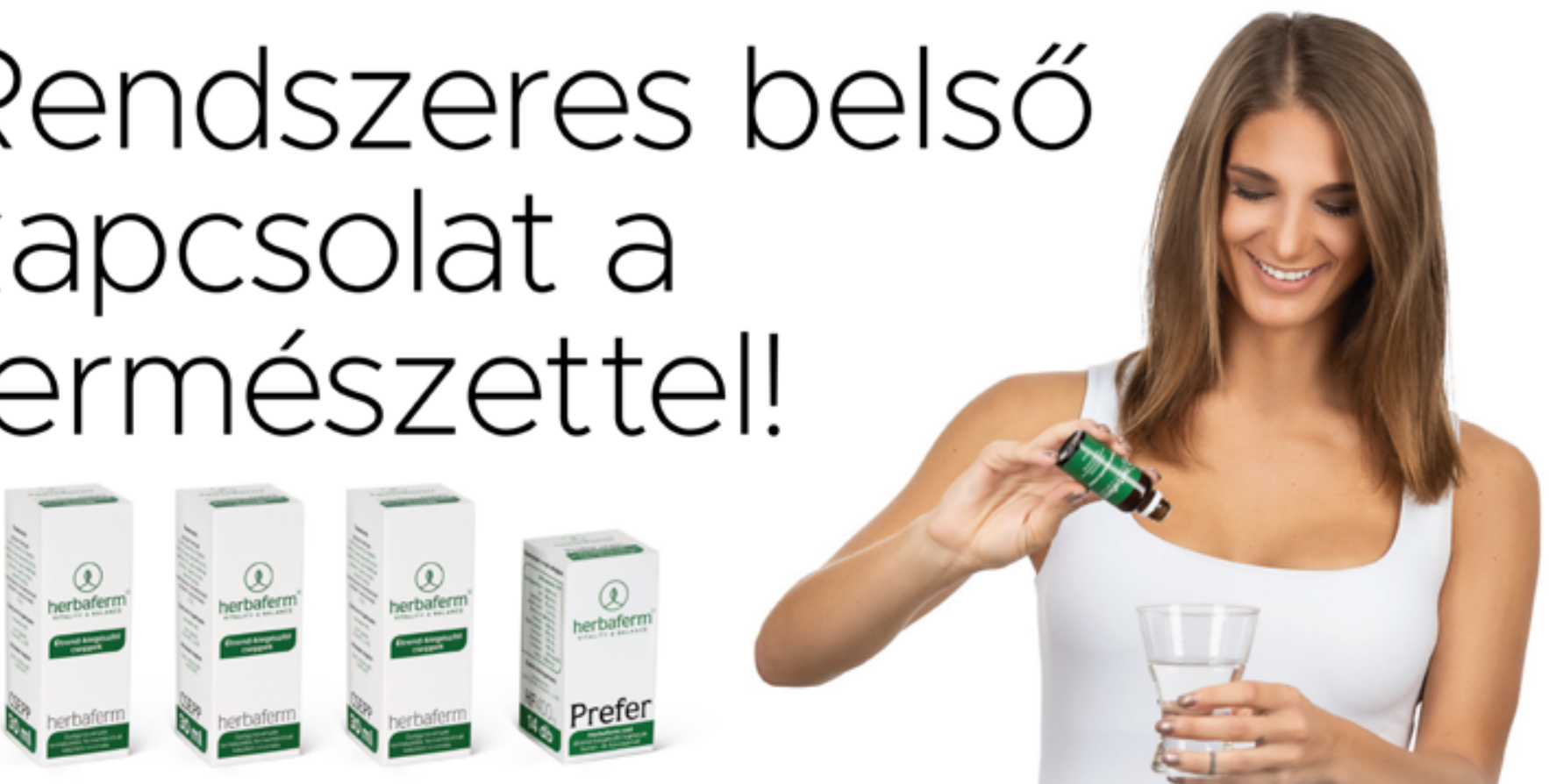

Természetes mikrobák életközösségével fermentált gyógynövény-kivonat A modern életmódból hiányzó természetes életközösség pótlása a Herbaferm cseppek mindennapos használatával. oGyél: 20075/2018 Kapcsolat és bővebb információ: www.herbaferm.hu

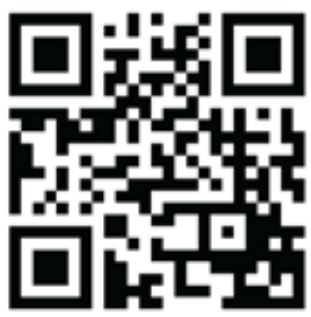

